\title{
An Analysis of the Current Directions in the Development of Green Energy
}

\author{
Leonid Hr. Melnyk ${ }^{1}$, Anatolijs Mahnitko ${ }^{2 *}$, Renata Varfolomejeva ${ }^{3}$ \\ ${ }^{1}$ Department of Economics and Business Administration, Sumy State University, Ukraine, ${ }^{2,3}$ Institute of Power Engineering, \\ Riga Technical University, Latvia
}

\begin{abstract}
An analysis has been conducted on the current directions in the development of traditional and non-traditional sources of energy that do not have a negative environmental impact. The progress regarding the current level of energy production by means of the Sun and wind has been shown. The prospects of using wind energy to solve the energy resource accumulation problem are outlined. One of the directions of the development of non-traditional energy is hydrogen energy, which solves the issue of utilization of hydrogen as a future energy resource and one of the possible ways of energy resource accumulation. As the hydrogen production technology develops in the direction of cost lowering, also the level of utilizing hydrogen energy will increase since the reserves of hydrogen contained in natural water resources are practically unlimited. An important feature of green energy is the need to integrate the capacities into united complexes not only on a country-by-country scale but also on the scale of large supranational regions.
\end{abstract}

Keywords - Energy accumulation, hydrogen energy, renewable energy sources, traditional and non-traditional energy resources, wind energy.

\section{INTRODUCTION}

The whole history of mankind consists in the search for and utilization of energy resources for subsistence, development, increase of life standard and welfare. The last-mentioned phenomenon is largely measured by the level ( $\mathrm{kWh} /$ person) of electric energy utilization per one inhabitant of the country. This indicator, in its turn, depends on the level of development of the electric energy industry, which is a fundamental economy sector for all of the world's developed countries.

All the energy resources on the Earth are the products of the ceaseless activity of the Sun. These energy resources can be conditionally divided into two main groups: resources that are accumulated by nature and are in most cases non-renewable and those that are not accumulated by nature but are continuously renewed. The first group includes the reserves of fossil fuel: oil, coal, shale, peat, natural gases, thermonuclear and nuclear energy. The second group includes solar radiation, wind, rivers, sea waves and tides, the Earth's internal heat, and biomass, which either exist continuously or periodically emerge in the environment. The energy resources of this group are renewable energy sources (RES) and constitute the basis for the development of "green" energy, which does not have any harmful impact on the condition of the external environment.

Over the last two centuries, mankind has made an evolutionary journey of augmenting energy production by means of fossil organic fuels: coal, oil, natural gas and uranium for nuclear energy. At present, the utilization of traditional fossil fuels has the following peculiarities:

- A discrepancy between the increasing need for fuel/energy resources (FER) and the possibility of meeting this need;

- Exhaustibility of organic fuels, which will considerably manifest itself towards the middle of the 21 st century;

- A high level of environment pollution when using organic fuels.

A breakdown of the total atmospheric pollution by source is shown in Table I [1].

This harmful environmental impact results in global warming, acid rains, an increased concentration of harmful substances in the atmosphere, ground and water. These problems can be solved by increasing the efficiency of utilizing traditional fuel/energy resources or diminishing the share of their utilization in the overall amount of renewable energy sources. Illustrative examples of such solutions can be provided by the following facts that were observed in 2015: investments into the renewables sector reached 329 billion US dollars [1], the global coal consumption diminished by 47 million tonnes [1] and the total capacities of the world's wind power plants exceeded the total capacities of the nuclear power plants for the first time [1].

TABLE I

BREAKDOWN OF TOTAL ATMOSPHERIC POLLUTION BY SOURCE

\begin{tabular}{|l|c|}
\hline Source of pollution & $\begin{array}{c}\text { Total atmospheric } \\
\text { pollution, } \%\end{array}$ \\
\hline Motor transport & 60 \\
\hline Power plants and heating & 22 \\
\hline Industry & 15 \\
\hline Refuse burning & 3 \\
\hline
\end{tabular}

Substantial prospects of considerably diminishing atmospheric emissions arise due to the electrification of motor transport, which is the dominant source of environment pollution. In the future, as far as the production of electric energy itself changes over to renewable energy sources, this effect is to become even stronger due to the environmental component.

Successful commercial dissemination of electric cars is facilitated by the technical characteristics achieved by them: possible travel distance (with one charging session) - from $100 \mathrm{~km}$ to $400 \mathrm{~km}$, developed speed - up to $200 \mathrm{~km} / \mathrm{h}$, acceleration to $100 \mathrm{~km} / \mathrm{h}$ in 3 seconds..

Electric car charging station networks are being set up at an increasingly fast rate. The express charging speed (up to

\footnotetext{
${ }^{*}$ Corresponding author.

E-mail address: Anatolijs.Mahnitko@rtu.lv
} 
$75 \ldots 80 \%$ of battery capacity) is $20 \ldots 30$ minutes [1]. Along with the increase in the charging speed of electric storage batteries, also their capacity has increased [1].

For most of the world's countries, the solving of the above problems is of extreme importance, since it influences their energy security (ES), which is one of the main components of their economic security.

Energy security is determined by the possibility to provide a country with fuel/energy resources that guarantee full-fledged functioning to the country. For example, Ukraine, like most of the world's countries, is only partly provided with the traditional types of primary energy and hence needs to import them [1]. As regards Latvia, it is practically completely dependent on imports of the traditional types of energy resources [1].

All of the above testifies to the topicality of investigations in the field of searching for and substantiation of the use of energy sources that comply with the requirements for "green" energy, which allows avoiding the use of fuel and its combustion processes [1].

As compared to hydrogen and nuclear energy, RES practically rule out any costs related to the extraction and processing of raw energy sources. Such fields of renewable energy as solar and wind energy ensure energy production with minimum labour input at the resource utilization stage. At the same time, the creation of the renewable energy generation equipment itself is associated with considerable capital investments. The repayment periods of this equipment depend on its type and power rating.

According to Directive 2009/28/EC of the European Parliament and of the Council of 23 April 2009 on the promotion of the use of energy from renewable sources, each of the EU member states has to increase the share of renewable energy sources in their electricity markets [1]. For example, Latvia has to increase its RES share to $7.1 \%$ by 2020 (Lithuania and Estonia - to $8 \%$ and $7 \%$, respectively). This increase is planned mainly due to the use of HPPs and wind power plants (WPPs) since wind farms are increasing their share in energy production. It is also necessary to pay attention to the reliability of power supply, which requires provision of backup for the WPPs in case of windless weather.

At the Paris climate summit (Paris, December 2015), a project for the complete transition to renewable energy sources (RES) of 139 countries was presented [1].

The material of the present article consists of eight chapters. Chapter 1 shows the topicality of the problem. Chapter 2 reviews the essence of the currently most widely used RES. Chapter 3 is dedicated to hydrogen energy. Chapter 4 provides a brief statement of the RES utilization problem. Chapter 5 presents analysis and achievements in the field of energy accumulation. Chapter 6 provides a brief review of smart control systems of various levels. Chapter 7 points out the need for a transformation of the communication basis of green energy and the basis of the EnerNet energy information system. Chapter 8 presents the main conclusions.

\section{TRADITIONAL TYPES OF RES}

\section{A. Solar Energy}

The Sun is a giant "thermonuclear reactor" that operates on hydrogen and every second, by melting, processes 564 million tons of hydrogen. Due to the protective shell of the atmosphere, only part of this energy reaches the Earth's surface [1].

Solar radiation creates not only favourable conditions for the existence of all life but also the opportunity for a person to use it for their own purposes. The energy emanating from the Sun's propagates in the form of electromagnetic radiation in the range from short-length radio waves of $30 \mathrm{~m}$ to the X-ray wavelength of $10^{-10} \mathrm{~m}$. Part of the electromagnetic waves is reflected and / or absorbed by the atmosphere and clouds. Part of the electromagnetic radiation from the Sun (solar radiation) reaching the Earth's surface concentrates mainly in the wavelength range of $0.2 \ldots 3.0 \mu \mathrm{m}$.

The Sun's energy can be directly used for obtaining heat. Systems that convert the energy of solar radiation into heat are conventionally divided into two groups: active and passive systems. In active systems, the capturing and conversion of solar energy takes place in special devices - solar collectors. Solar collectors are usually installed on the roofs of buildings and do not affect the scenery and environmental condition of the vicinity or require additional land allotments. In active solar heating systems, the heat is transferred from the solar collector to an accumulator and further to the room. In passive systems, the device itself functions as the receiver of radiation. Passive systems are simpler and cheaper as compared to active ones, since they do not require additional devices for the absorption, conversion and distribution of solar energy. Passive utilization of solar energy with the aim of providing heating to buildings is effected by means of architectural and design solutions. Combined solar systems envisage simultaneous use of solar collectors for hot water supply and space heating. A very important aspect is that by means of solar energy it is also possible to obtain electricity. By using solar energy, electricity can be obtained in heating systems in which heat from fuel combustion is replaced by a flow of concentrated solar radiation. In regions with a high level of solar radiation, it can be used for obtaining steam, which by turning a turbine produces electricity. All solar power plants are designed on the basis of solar power installations, which by means of optical systems concentrate solar energy to heat up the working body to a temperature that ensures efficient operation of heat engines. Integration of power-industry capacities into united complexes not only on the scale of one country but also on the scale of large transboundary regions enables an improvement in their energy efficiency. For example, during the daytime the economies of Europe can be provided with electricity by the solar power plants of the southern countries (including African countries) whereas at night the energy can be supplied by the hydropower plants of the Scandinavian countries.

The solar radiation accumulated by helioenergetic devices replaces energy produced by means of environmentally harmful technologies. This feature represents the main environmental advantage of solar energy. A disadvantage that has to be mentioned regarding free-field solar power plants where energy transformation is related to the concentration of solar radiation, is the need to allot considerable territories. So, the average area 
required per $1 \mathrm{MW}$ of a tower-type solar power plant for the turning mirrors is approx. $0.035 \mathrm{~km}^{2}$. As regards solar power plants on the whole, the ratio between the area in hectares per one thousand kilowatts of capacity ranges from 1 to $8 \mathrm{ha}$ /thousands $\mathrm{kW}$ in various countries of the world.

The possibilities of solar radiation are confirmed by an example of a kind of a record that was observed in Germany. According to the Fraunhofer Institute of Solar Energy Systems (Fraunhofer ISE), on a sunny day, namely, on June 9, 2014, Germany's solar cells produced more than half $(50.6 \%)$ of the energy consumed on that day in the country [1].

\section{B. Wind Energy}

Wind energy is continuously renewable and inexhaustible as long as the Sun is shining (heating the Earth). Wind arises on the Earth due to the fact that its surface is inhomogeneously heated up by the Sun. The power of wind is one of the most ancient and most economical sources of energy used by mankind.

The amount of wind energy available around the globe is estimated at approx. 175...220 thousand TWh annually and its capacity reaches $(20 \ldots 25) 109 \mathrm{~kW}$. The amount of available wind energy exceeds the summary global energy consumption about 2.5 times. It is deemed that only five per cent of this amount can be put to use [1].

The modern wind installations are sophisticated automated electromechanical complexes that transform the energy of wind into electric energy. The main elements of a wind-power unit are as follows: the rotor (the blades of the wind turbine), the generator, the gearbox, the tower and the operating mode control system. Depending on the type of wind-power installations, these can produce electric power at low-wind conditions and even at no-wind conditions [1]. In the latter case, it is necessary to have a temperature difference between the base and the top of the tower of not less than $10^{\circ} \mathrm{C}$. This can be achieved by secondary heat resources, for example.

When producing electric energy, wind installations practically do not pollute the atmosphere (the environment). Yet they have the following environmental impact: land alienation and landscape changes are necessitated; a noise effect emerges, as well as radio interference and vibration; the high metal content in the installations causes pollution in the metal extraction and processing cycle.

The potential of wind energy is exemplified by the situation in Denmark on July 9, 2015. On this extremely windy day, Denmark's wind power facilities generated $144 \%$ of the amount of electricity consumed in the country on the same day [1].

The development dynamics of wind energy in Ukraine is shown in Table II. The wind potential in the Baltics in 2013 was $640 \mathrm{GWh}$; it is expected that in 2020 the figure will be $1817 \mathrm{GWh}$.

TABLE II

DYNAMICS OF DEVELOPMENT OF WIND POWER IN UKRAINE

\begin{tabular}{|l|l|l|l|l|l|}
\hline Index & Units & 2005 & 2010 & 2020 & 2030 \\
\hline $\begin{array}{l}\text { Installed capacity } \\
\text { of wind farm }\end{array}$ & GWh & 0.05 & 0.46 & 0.86 & 1.14 \\
\hline $\begin{array}{l}\text { Annual electricity } \\
\text { production }\end{array}$ & billion $\mathrm{kWh}$ & 0.05 & 0.60 & 1.51 & 2.00 \\
\hline
\end{tabular}

\section{Hydroenergy}

Today's hydropower industry is the most economical and environment-friendly way of obtaining electricity as compared to other fields of the electric power industry [1]. One doubtless advantage of hydropower plants (HPPs) lies in their stable operation within the power system regardless of the time of the day.

Small hydropower moves even further in this direction [1]. Small hydropower plants help to preserve the natural landscape and do not have an environmental impact, be it at the operation stage or in the construction process. Unlike other renewable energy sources (RES), for example, solar or wind energy, the small-scale hydropower industry is practically independent of weather conditions and is capable of ensuring stable deliveries of cheap electricity to the consumer. The operation of small HPPs has no harmful impact on water quality, fully preserving the initial natural properties of the water. The fish in the rivers survive and the water can be used for water supply.

Large-scale HPPs impact the environment, changing the thermal, hydrological and climatic conditions of the area. Such changes are not typical of small HPPs since, in most cases, these use natural water head and do not require construction of large hydrotechnical structures (dams).

\section{Biofuel Energy}

The substance that makes up plants and animals is conditionally termed biomass. Plant biomass is one of the most ancient primary energy sources on the Earth. The basis of biomass is made up by carbon compounds, which emit heat when burned or during natural decay. In bioenergetics, biomass can be used as a renewable energy source. The term "biomass" covers all the types of vegetation, plant-based agricultural waste and waste from woodworking and other industries that are of any considerable calorific value and can be used as fuel. In a wider sense of the word, biomass also encompasses waste that is not always plant-based, which is due to the identical principle of utilization. The most frequent types of biomass are straw, grain processing waste after thrashing, wood waste (chips, bark, shavings), fallen leaves, branches of trees, etc.

The most effective technologies for using biomass are thermochemical ones: direct combustion, gasification, pyrolysis and methane fermentation (production of biogas) [1].

Another effective direction of RES utilization is biogas energy. The biogas-related energy extraction methods use chemical methods of waste degassing. Hereby, formation of closed cycles of raw material utilization is encouraged, enabling an improvement of the environmental situation. Today, European biogas installations are capable of replacing fifteen coal-fuelled power plants with an average capacity of $500 \mathrm{MW}$ $[1]$.

\section{Hydrogen As A NON-TRAditionAl RENEWABLE ENERGY RESOURCE}

Among non-traditional sources of energy, hydrogen seems to be the most promising one for the next decades, as it has no harmful environmental impact when used as a fuel. Hydrogen is the energy resource of tomorrow, regardless of the fact that the present methods of its extraction require considerable capital input. 
The most obvious method of obtaining hydrogen is the decomposition of water into hydrogen and oxygen. There is a whole range of known methods of water decomposition: the chemical method, the thermochemical method, electrolysis, etc. All of these methods have a considerable drawback: the technological process of obtaining hydrogen uses highpotential energy, which is produced, in its turn, by using scarce fossil fuel (coal, natural gas, oil products). Such hydrogen production will, of course, always remain costly and environmentally harmful, and, as a result, unpromising. Various ways are being tried out to overcome the contradiction between the production of hydrogen and its use.

Above 600 companies, corporate groups, university laboratories and public research and technology bodies in Western Europe, the United States, Australia, Japan, and Canada are working hard at the problem of making hydrogen production cheaper [20].

Also, exotic projects of large-scale hydrogen production by means of bacteria are being developed. The principle of their operation is based on photosynthesis, involving absorption of sunlight, for example, by fast-growing blue-green algae. These algae can serve as nutrition for some types of bacteria, which within their life cycle separate hydrogen from water, the reserves of which are unlimited and renewable. However, to implement this idea, a number of scientific and engineering problems need to be solved.

From a power generation point of view, hydrogen is an alternative to oil and natural gas. The prospects of using hydrogen are based on the following circumstances:

- The reserves of hydrogen contained in water are practically inexhaustible;

- The calorific value of hydrogen is several times higher as compared to natural gases;

- Hydrogen can be used as fuel to obtain heat and electricity as well as in various kinds of engines;

- Hydrogen is an environment-friendly type of fuel.

\section{THE UTILIZATION OF DiFFERENT TYPES OF RENEWABLE ENERGY SOURCES}

Scientific achievements make it possible to apply various types of renewables to produce energy. It becomes realistic to use not only the energy of the Sun, wind, etc. Any potential difference can become a source of energy. It can be the difference of temperatures, pressures, heights and other physical characteristics. Just about everything that moves begins transforming into a source of energy [21].

A wind generator design has appeared that is capable of catching just a slight breeze. These generators are not at all similar to the huge blades of the wind installations that have already become familiar, yet, collected in large quantities, they become an appreciable source of energy. There exist wind power plants that are capable of working at nearly no-wind conditions. These make use of the difference between the pressures at various heights (up to $700 \mathrm{~m}$ ) [22]. In Sweden, a TV tower was turned into a power plant. For that purpose, the tower was provided with thousands of electrostatic lightweight components generating electricity from friction between themselves [23]. In America, a power plant has been made out of a motorway, where energy is generated by cars moving along it. Likewise, it is learned in Europe how to utilize the energy of bicycles riding along a bike path [24], [25].

In the developed countries it is becoming commonplace to use the temperature difference under the ground and on its surface. This is related to the use of the so-called heat pumps. In winter, they can be used for space heating, and in summer for cooling. Moreover, both the former and the latter are provided with a minimum of energy consumption.

The spectrum of technical processes utilizing chemical energy for transformation of biomass waste (production of biogas, bioethanol, biodiesel, etc.) is expanding.

\section{THE ACCUMULATION OF ENERGY}

This development direction of energy-utilizing technology makes it possible to overcome the contradiction between the time of energy production and the time when it is needed.

As is known, the operation of thermal power plants has the highest efficiency in the case of a continuous operating mode, i.e. when their power production remains constant throughout the 24-hour period. As concerns nuclear power plants, they cannot change their operating mode at all. Even a short-term shutdown of this type of plants is accompanied by large expenses, both in technical and economic terms. At the same time, the electric power demand throughout the 24-hour period is characterized by a corresponding consumer load schedule, which shows inhomogeneous consumption during the 24-hour period. Thus, for example, during the daytime (when most industrial enterprises are active) the load is considerably higher than at night when the enterprises are shut down and people go to bed. Diminished electricity consumption necessitates diminished amounts of electricity production, which is unprofitable in itself, since at the peak hours of electricity consumption, a deficit in the possible production amount may be felt. A natural solution to this situation lies in the existence of energy reserves, which brings to the foreground the problem of energy accumulation (storage). The accumulation problem becomes more topical as the degree of using solar and wind generators increases. However, since solar and wind energy is not always available, it is necessary to make advantage of its availability, producing energy in advance (as a reserve), although it may not be required at the moment. Yet such a course of action is useful only if there are reliable accumulators, which enable accumulation and storage of energy in an unlimited amount.

Part of the problem can be solved by means of our familiar electrical accumulators, still only part. Indeed, there will emerge a large amount of surplus energy (at practically no cost). As was discussed above, in the example of Denmark its wind power installations can on some days generate considerably more electricity than the country needs according to the consumption schedule. The same can be said about the situation in Germany and Spain, where solar batteries generate more than half of the electricity consumption in these countries. Consequently, a decisive potential is needed for storing large amounts of electricity produced at nearly no cost.

A power plant type that is widely used in the world's power industry is the pumped-storage hydropower plant (PSHPP), which uses electric power in the periods of lower load in the power system and releases electric power at the power system 
peak demand hours. A PSHPP has two water reservoirs - the upper one and the lower one. When electric power is needed, the PSHPP operates like an ordinary HPP; when the load diminishes, pumps are switched on to pump water from the lower reservoir to the upper one.

At present, considerable prospects of solving the problem of storage of the green energy reserve are seen in the development of hydrogen technologies. Hydrogen as one of environmentfriendly fuels (producing water when burned) can also be used as a base element in energy accumulation. As was pointed out above, wide use of hydrogen has up to now been made impossible by economic considerations. Their essence is such that at usual conditions, extraction of hydrogen requires the input of more energy than can be obtained when burning it. In these circumstances, using hydrogen as a fuel loses any rationale.

The utilization of hydrogen as a fuel for generating electricity can be rendered economically efficient if renewable energy sources (solar and wind energy etc.) are used for its extraction [26]. The surplus of the electric energy produced from RES can be used for procuring hydrogen. Thus, the problems of extracting hydrogen and accumulating (storing) the surplus electricity obtained by means of renewable energy sources (solar, wind energy) are interrelated and their effective solution depends on the development level of the energy accumulation technology.

At present, five main directions can be singled out, which could to a greater or lesser extent become promising for industrial application: pumped storage (involving natural and forced elevation of the water level at periods of energy surplus and utilization of stored energy at peak periods), electrical storage, hydrogen technologies, thermal storage, chemical storage (involving purposeful changes in the properties of substances by using the energy surplus or storage of organic substances with subsequent production of biogas or electricity). A whole range of examples testifying to successful implementation of these methods is known [27].

In the Atacama Desert (South America), a project of building a large-scale power plant is under way, involving both solar and hydropower generation. During the daytime, the electricity obtained by solar panels will raise sea water through a tunnel to the top of a mountain, where it will be stored in natural reservoirs. At night, the electricity will be generated by the falling of the water stored during the day [27].

The Schneider Electric company has developed a smart energy accumulation system. The system selects, on its own, the mode of energy accumulation (in case of surplus solar and wind energy) and the release of the energy to infrastructure entities if required [28].

The new electric car batteries manufactured by Samsung enable a travel distance of up to $600 \mathrm{~km}$ after one charging session [4]. In Germany, it is planned to invest approx. half a billion euro into the improvement of the hydrogen fuel cell technology; these can turn into efficient accumulators of energy [24], [29].

In Switzerland, scientists have proposed a very cheap system for obtaining hydrogen fuel (artificial synthesis of water) by means of solar energy [30]. The system provides a high conversion efficiency $(12.3 \%)$.
A solar power plant in Nevada (United States) generates electricity around the clock. During the daytime, along with the generation of capacity, this power plant heats up a gigantic salt tower up to a temperature of over $500{ }^{\circ} \mathrm{C}$. Using this heat, the power plant also works at night [31].

Researchers from the Massachusetts Institute of Technology (United States) have developed a new material, which is capable of storing solar energy in the form of chemical change rather than heat. The chemical system can store the energy for an indefinite time in a stable molecular configuration. Energy release can be set off by a small jolt of heat, light or electricity [32].

The Pacific Northwest National Laboratory has developed an accumulator based on liquid electrolytes. They substitute for expensive metal electrolytes (lithium ion batteries). This allows diminishing the prime cost of energy storage by $60 \%$ and improving other indicators (first and foremost, environmentfriendliness and stability over time) [33].

\section{THE SMART CONCEPT}

The reduction of the level of air pollution is currently facilitated by the formation of a number of smart control systems of various levels: the production operation, workplace, shop, smart manufacturing, building, transport mainline, city (infrastructure), and country levels. For example, similar logistics systems (Google Transport) already operate in many countries.

In modern conditions a realistic opportunity is to create smart control systems that will not only assume the function of optimizing production processes in space and time, but also serve as an integrating principle, unifying the activities of many, often hundreds of thousands of economic links. In particular, "smart" Internet systems successfully solve the problems of logistics of manufacturing enterprises, including the tasks of finding the optimal resource providers, optimizing their delivery routes, etc.

Such systems are already available to users in many countries, including Ukraine. For example, the existing transport management system (Google Transport) is in a position of not only calculating the most efficient route for delivering goods to a certain point of destination, but also picking up cargo for the return journey - so as not to return empty.

Today we see the management of a network of different levels, "smart" factory, "smart" house, "smart" city, "smart" traffic artery. Yet all of them are formed and function on the basis of a permanent connection to the Internet [34], [35].

\section{TRANSFORMATION OF THE COMMUNICATION FRAMEWORK OF GREEN ENERGY}

The very specificity of "green" energy requires a radical transformation of its communications framework. Moreover, we can confidently say that without such reforms, "green" energy cannot be implemented. The main arguments are as follows:

Unlike traditional energy generation, which is based on large generating capacities, "green" energy generation uses an enormous amount of small-scale generating installations (in the EU alone, hundreds of millions of entities are being planned). 
This presupposes a considerable deconcentration of energy sources. In fact, every family, while remaining a consumer of energy, also becomes an energy producer. Deconcentrated energy sources of this kind can become a real generating force only if they are to be united into system complexes and informationally organised.

Another peculiarity of "green" energy is the narrow domain of favourable conditions for the functioning of each of the types of renewable energy. For example, solar generators only work during the daytime, wind generators - only at windy conditions, biogas generators - mainly in summer and autumn, etc. Besides, each of these has its own spectrum of optimum operating conditions. All of the above leads to the need for a considerable diversification of the power basis of the economy.

The third significant peculiarity is related to the need to integrate energy capacities into united complexes not only on the scale of one country but also on the scale of large transboundary regions.

In the EU, the fundamentals of an energy information system (EnerNet) are being formed, which is the energyrelated counterpart of the Internet. This system has to ensure the collection (from many sources), transmission, storage, conversion and utilization of electricity in the most efficient mode possible.

Of course, the very idea of creating a united energy network encompassing a considerable territory is not new. Similar networks are in place in such large countries as the United States of America, China, and India. A united power system also existed in the Soviet Union.

The experience in relation to the functioning of networks (power systems) of this type is being used in the formation of EnerNet. However, the level of the informational complexity of the tasks set for EnerNet is incomparably higher. Whereas the earlier power systems mainly had to do with the redistribution of energy, the complex of tasks faced by new-generation power systems is considerably more demanding. They will have to ensure the collection (purchase) of electricity from millions of economic subjects using hundreds of millions of various generators of various kinds and types; its conditioning (bringing it to standard parameters), transmission, storage, conversion and utilization of the energy in the most efficient modes possible, as well as ensure the stability of power systems.

\section{CONCLUSION}

At present, the fundamentals of a new type of economy are in the making. Its essence lies in the interaction of transformations of three key groups of factors, i.e. energy, information and communication factors.

This type of economy is termed green economy (being based on environment-friendly technologies).

The decisive factors in the transition to this new type of economy are as follows: transition to renewable sources of material resources and energy (which radically changes the material and energy basis of production), creation of computer and digital technologies (which change the informational basis of the functioning of society), formation of the Internet as a united global memory system (which integrates individual local subsystems into the world's united economic system).

\section{ACKNOWLEDGMENT}

The work presented in this paper has been co-financed by the National Research Program LATENERGI (2014-2017).

\section{REFERENCES}

[1] D. F. Kozin and S. V. Volkov, Vodorodnaja ènergetika i èkologija, Kiev: Naukova dumka, 2002. (in Russian)

[2] N. Fedosenko, In 2015 investments in renewable energy amounted to 329 billion dollars [Online]. Available: http://ecotown.com.ua/news/V-2015mu-investytsiyi-u-vidnovlyuvanu-enerhetyku-syahnuly-329-milyardivdolariv/ (In Ukrainian) [Accessed on: 01.03.2016.]

[3] N. Yakovlyeva, The world in 2015 reduced coal consumption by 47 million tons [Online]. Available: http://ecotown.com.ua/news/ U-2015-rotsi-svit-zmenshyv-spozhyvannya-vuhillya-na-47-mln-tonn-/ (In Ukrainian) [Accessed on: 01.03.2016.]

[4] T. Turlikyan, New battery from Samsung will allow electric car to travel $600 \mathrm{~km}$ on a single charge [Online]. Available: http://ecotown.com.ua/ news/Novi-batareyi-vid-Samsung-dozvolyayut-elektromobilyamproyikhaty-600-km-na-odnomu-zaryadi-/ (In Ukrainian) [Accessed on: 01.03.2016.]

[5] N. Yakovlyeva, Schneider Electric developed a smart energy storage system EcoBlade, [Online]. Available: http://ecotown.com.ua/news/ Schneider-Electric-rozrobyla-rozumnu-systemu-nakopychennyaenerhiyi-EcoBlade/ (In Ukrainian) [Accessed on: 01.03.2016.]

[6] At Stanford have created a battery for gadgets and electric vehicles, charging per minute [Online]. Available: http://idtech.biz/news/ item.php?131584 (In Russian) [Accessed on: 01.11.2015.]

[7] A. Mahnitko, J. Gerhards, O. Linkevics, R. Varfolomejeva, and I. Umbrasko, "Small Hydropower in Latvia and Intellectualization of its Operating System," Latvian Journal of Physics and Technical Sciences, vol. 50, no. 6, pp. 3-15, Jan. 2013. https://doi.org/10.2478/lpts-2013-0036

[8] O. Linkevics, M. Balodis, A. Mahnitko, and K. Mjaduta. "Modeling of Wind, Hydroelectric and Thermal Power Plant Coordinated Dispatch in Latvian Power System," in Proceedings of the 55th International Scientific Conference on Power and Electrical Engineering of Riga Technical University (RTUCON), 14-16 October, Riga: RTU Press, 2014, pp. 167-171.

[9] Statistical data from Central Statistical Bureau of Latvia [Online]. Available: http://www.csb.gov.lv/en/dati/statistics-database-30501.html

[10] For 139 countries of the world [Online]. Available: http://ecotown.com.ua/ news/Dlya-139-krayin-svitu-v-tomu-chysli-dlya-Ukrayiny-stvoreno-planvidmovy-vid-vykopnoho-palyva-do-2050/ (In Ukrainian) [Accessed on: 01.03.2016.]

[11] New record for Germany: $50.6 \%$ of energy per day derived from solar, [Online]. Available: http://geektimes.ru/post/227029/ (In Russian) [Accessed on: 01.11.2015.]

[12] T. Turlikyan, In the USA the number of employees in the solar sector for the first time exceeded the oil industry, [Online]. Available: http://ecotown.com.ua/news/U-SSHA-kilkist-pratsivnykiv-sonyachnoyisfery-vpershe-perevyshchyla-naftovu-promyslovist-/ (In Ukrainian) [Accessed on: 01.03.2016.]

[13] Solar and Wind Just Passed another Big Turning Point [Online]. Available: http://www.bloomberg.com/news/articles/2015-10-06/solarwind-reach-a-big-renewables-turning-point-bnef [Accessed on: 10.03.2016.]

[14] Solar Power. Clean Technica [Online]. Available: http://cleantechnica.com/solar-power/ [Accessed on: 01.03.2016.]

[15] Denmark Just Produced $140 \%$ of its Electricity Needs with Renewable Wind Power. Earth we are on [Online]. Available: http://www.ewao.com/ a/1-denmark-just-produced-140-of-its-electricity-needs-with-renewablewind-power/ [Accessed on: 01.11.2015.]

[16] A. Mahnitko, J. Gerhards, V. Oboskalov, T. Lomane, and R. Varfolomejeva, "A Model for Maximizing the Profit of a HPP Cascade Considering Hydraulic Link via Reservoirs," in 2016 IEEE 16th International Conference on Environment and Electrical Engineering (EEEIC), 7-10 June 2016, Florence, Italy.

[17] A. Mahnitko, J. Gerhards, T. Lomane, R. Varfolomejeva, V. Oboskalov, and K. Koljasnikov "Maximizing the profit of a HPP cascade considering Hydraulic," in PPE-2016. XIV International Scientific \& Technical Conference Problems of Present-day Electrotechnics-2016, June 6-10, 2016, Kyiv, Ukraine. 
[18] R. Varfolomejeva, A. Sauhats, I. Umbraško, and Z. Broka, "Biogas Power Plant Operation Considering Limited Biofuel Resources," in Proceedings of the IEEE 15th International Conference on Environment and Electrical Engineering, Rome, Italy, pp. 570-575, Jun. 2015.

https://doi.org/10.1109/eeeic.2015.7165225

[19] Trends in the biogas market in Europe (2015) [Online]. Available: http://goo.gl/19AFbm (In Russian) [Accessed on: 01.03.2016.]

[20] L. Hr. Melnyk, "Innovation Potential of the Third Industrial Revolution," Mechanism of Economic Regulation, No. 1, pp. 9-32, 2016. ISSN 17268699 (print)

[21] Shoes gathers kinetic energy while walking [Online]. Available: http:/www.facepla.net/the-news/tech-news-mnu/5384-обувь-собираетэнергию.html (In Russian) [Accessed on: 01.03.2016.]

[22] In the U.S., has developed an innovative power plant that runs on wind, [Online]. Available: http://zeleneet.com/amerikancy-razrabotaliinnovacionnuyu-energogeneriruyushhuyu-stanciyu-rabotayushhuyu-otvetra/13043/ (In Russian) [Accessed on: 01.03.2016.]

[23] Hairy skyscraper to be built in Sweden. Swedish architectural Studio Belatchew Arkitekter [Online]. Available: http://realty.rbc.ru/articles/ 21/05/2013/562949987015846.shtml (In Russian) [Accessed on: 01.10.2015.]

[24] R. A. Perelet, Green economy in EU: Policy and practice [Online]. Available: http://www.wecoop-project.org (In Russian) [Accessed on: 01.06.2015.]

[25] A. V. Lishchuk, The Netherlands, there was the world's first solar bike path [Online]. Available: http://ru.golos.ua/suspilstvo/14_10_31_v niderlandah_poyavilas_pervaya_v_mire_solnechnaya_velodorojka (In Russian) [Accessed on: 01.11.2015.]

[26] A. Sauhats, H. H. Coban, K. Baltputnis, Z. Broka, R. Petrichenko, and R. Varfolomejeva, "Optimal investment and operational planning of a storage power plant," International Journal of Hydrogen Energy, vol. 41, no. 29, pp. 12443-12453, Aug. 2016. https://doi.org/10.1016/j.ijhydene.2016.03.078

[27] A master plan of hydropower plant in the desert of South America [Online]. Available: http://facepla.net/the-news/energy-news-mnu/5359. гидроэлектростанции-в-пустыне.html (In Russian) [Accessed on: 01.03.2016.]

[28] N. Yakovlyeva, Schneider Electric developed a smart energy storage system EcoBlade, [Online]. Available: http://ecotown.com.ua/news/ Schneider-Electric-rozrobyla-rozumnu-systemu-nakopychennyaenerhiyi-EcoBlade/ (In Ukrainian) [Accessed on: 01.03.2016.]

[29] Life with algae. A green city. Alternative energy [Online]. Available: http://speedsurfing1.appspot.com/green-city.su/zhizn-s-vodoroslyami/ (In Russian) [Accessed on: 01.11.2015.]

[30] Developed cheap hydrogen fuel, [Online]. Available: http://lenta.ru/ news/2014/09/25/perovsksolar/ (In Russian) [Accessed on: 01.03.2016.]

[31] N. Fedosenko, This innovative clock solar power [Online]. Available: http://ecotown.com.ua/news/U-SSHA-pratsyuye-innovatsiynatsilodobova-sonyachna-elektrostantsiya-/ (In Ukrainian) [Accessed on: 01.03.2016.]

[32] Developed a new polymeric material for storage of solar heat [Online]. Available: http://tesiaes.ru/?p=15061 (In Russian) [Accessed
[A on: 01.03.2016.]

[33] A new battery will cost $60 \%$ less than the existing standard [Online]. Available: $\quad$ http://www.facepla.net/the-news/tech-news-mnu/5340новый-аккумулятор.html (In Russian) [Accessed on: 01.03.2016.]

[34] N. Eremina, The third industrial revolution. Economy growth [Online] Available: http://www.gazeta.ru/growth/2015/05/12_a_6683125.shtml (In Russian) [Accessed on: 01.10.2015.]

[35] If China's cities become "smarter" west [Online]. Available: http:/www.cisco.com/web/RU/news/releases/txt/2016/02/22a.html (In Russian) [Accessed on: 01.03.2016.] 